\title{
Design and Application of Intelligent Monitoring System for Laminated Henhouse with Six Overlap Tiers Cages
}

\author{
Hua-Long Li, Xuan-Jiang Yang \\ Institute of Intelligent Machines, Chinese Academy of \\ Sciences, Hefei, China \\ University of Science and Technology of China, Hefei, \\ China \\ E-mail: lihualong2007@163.com
}

\author{
Jun-Ying Li, Kai Zhan \\ Institute of Animal Husbandry and Veterinary, \\ Agricultural Academy of Anhui Province, Hefei, China \\ E-mail: lihualong2007@163.com
}

\author{
Miao Li, Hui-Yi Gao, Ze-Lin Hu \\ Institute of Intelligent Machines, Chinese Academy of Sciences, Hefei, China \\ E-mail: lihualong2007@163.com
}

\begin{abstract}
Because of high breeding density, the laminated henhouse with six overlap tiers cages microclimate has more influence to layers health and production performance. At present, the environmental measuring parameters and the measuring points are too less to reflect the whole henhouse environment. To solve this problem, we proposed an intelligent monitoring system and designed a kind of sensor distribution topology for henhouse complex structure. It can realize the real-time online environmental monitoring of the whole henhouse. The monitoring experiment was carried out in a henhouse in Hubei province. And the evaluation of the henhouse environment was scientifically analyzed. In fact, we find that his system runs stably, accurately and effectively, and has important practical significance and good application prospect in large-scale livestock precision farming.
\end{abstract}

Keywords-sensor; network; embedded system; henhouse; environmental engineering

\section{INTRODUCTION}

In recent years, the development of layer breeding in the direction of large-scale intensive. Because of high breeding density, the laminated henhouse with six overlap tiers cages microclimate has more influence to layers health and production performance. The henhouse environment control is becoming increasingly important. At present, various single parameter measuring instruments were used to measure environmental parameters, which have complicated operation and low detection efficiency. And the measuring points are too less to reflect the whole henhouse environment. It is unable to realize convenient and real-time online monitoring [1-4].

To solve this problem, we proposed an intelligent monitoring system and designed a kind of sensor distribution topology for henhouse complex structure. It can realize the real-time online environmental monitoring of the whole henhouse. The monitoring experiment was carried out in a laminated with six overlap tiers cages of Hubei Shendan healthy food Co., Ltd, Wuhan, Hubei. And the evaluation of the henhouse environment was scientifically analyzed, which can provide the reference for the standardization of automatic control of farm facilities optimization and upgrading.

\section{OVERALL DESIGN OF MONITORING SYSTEM}

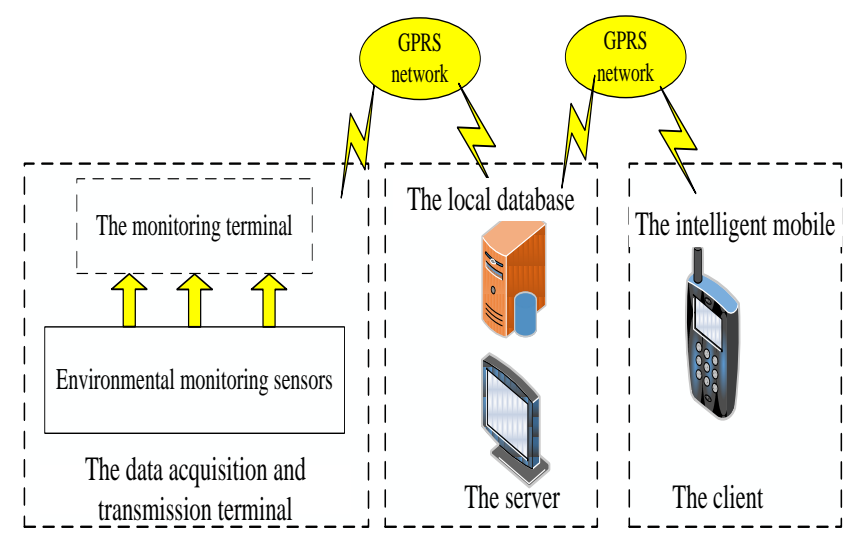

Figure 1. The framework of monitoring system

As Fig. 1, the system consisted of three parts: Data acquisition and transmission terminal, server and client [1012]. The function of data acquisition and transmission terminal is to monitor henhouse environmental information, including monitoring terminal and henhouse environment monitoring sensors.STM32F103VB (ARM 32-bit CortexM3 CPU) was used as the core processor in the monitoring terminal. All the sensors were connected to the monitoring terminal by RS- 485 bus. And the sampling interval and the sending time interval of the environmental parameters can be set through the button module. The collected environmental data was packaged by STM32F103VB and sent to the GPRS network through the GPRS module. The server was used to receive and process data and the local database was used stored them, which can be convenient for users to query. The data of the environmental parameters was viewed by the intelligent mobile client from the database of the server, to facilitate the use of users [5-6]. 


\section{A. Hardware Design}

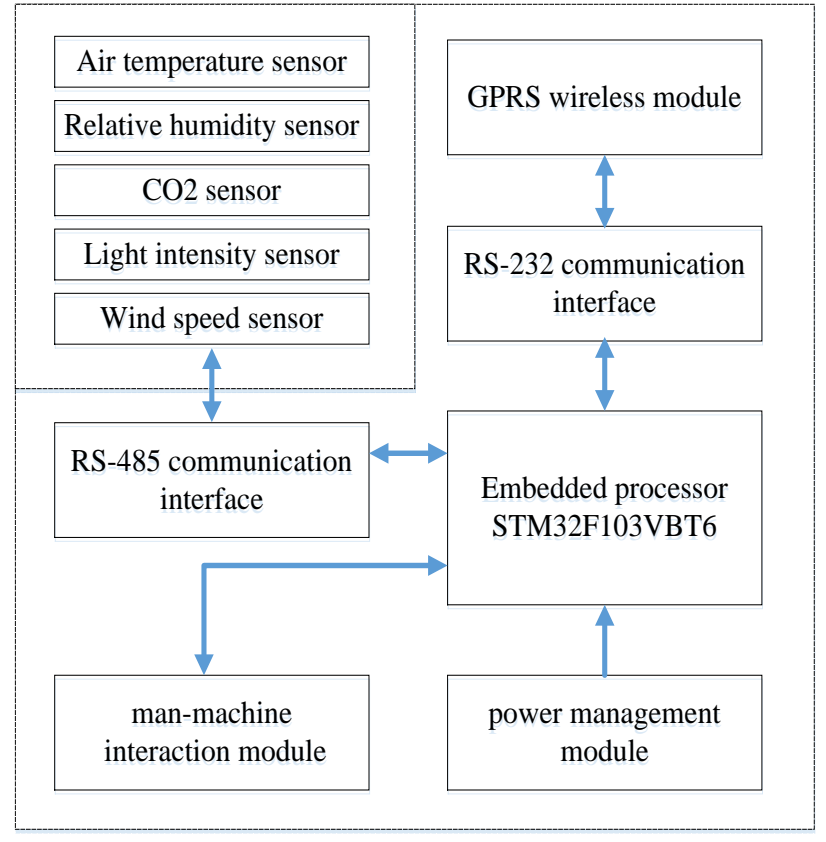

Figure 2. The structure of data acquisition and transmission terminal

The structure of data acquisition and transmission terminal was shown in Fig. 2. The monitoring terminal included microprocessor STM32F103VBT6, RS-485 communication interface, RS-232 communication interface, GPRS wireless module, man-machine interaction and power management. RS-485 communication interface was used to connect environment monitoring sensors with STM32F103VBT6, to collect the henhouse environment real-time data. GPRS wireless module (Xiamen Caimore Communication Technology Co. Ltd) can realize the realtime transmission of environment data to the cloud server, which connect with STM32F103VBT6 through RS-232 communication interface. TCP transparent transmission mode with low power consumption were used in GPRS wireless module. The man-machine interaction module included a 4.3-inch LCD and a keyboard [7-8]. All environment parameters can be real-time displayed on the LCD, and the display module can be controlled. The keyboard was used for setting of the periodic sampling, filtering and the controlling mode of data transmission. Power management module includes a DC12V 48AH large capacity cell group and the corresponding power conversion circuit.

The environment monitoring sensors included the sensors of air temperature, relative humidity, light intensity, $\mathrm{CO}_{2}$ (CG-01, Hefei heinford Electronic Technology Co. Ltd. The measurement range of air temperature: $-40 \sim+85$, with the measurement accuracy: 0.3. The measurement range of relative humidity: 5\% 95\%, with measurement accuracy: $2 \%$. The measurement range of light intensity: 0 100Lux, with measurement accuracy: 1Lux. The measurement range of $\mathrm{CO}_{2}: \quad 0 \sim 1000 \mathrm{mg} / \mathrm{m}^{3}$, with measurement accuracy: 10 $\mathrm{mg} / \mathrm{m}^{3}$ ), wind speed (HD403TS2, Italy DELTA Co. Ltd. The measurement range: $0.08 \sim 5.0 \mathrm{~m} / \mathrm{s}$, with measurement accuracy: $0.2 \mathrm{~m} / \mathrm{s}$ ), All sensors have been calibrated before leaving the factory.

\section{B. Software Design}

The software of the whole system can be divided into 3 parts, namely, the monitoring terminal software, the server software, and the Android terminal application software. Monitoring terminal software is mainly to complete the collection of henhouse environmental data and send them to the GPRS network task

Monitoring terminal software code using $\mathrm{C}$ language, using Keil integrated development environment as a software programming and debugging platform.

The monitoring terminal software written by $\mathrm{C}$ language was mainly to complete the collection of environment data and send them to the GPRS network, using Keil integrated development environment as software programming and debugging platform.

To improve the reliability of the sensor measurement and reduce the measurement error caused by interference, the average filtering algorithm of anti-impulse interference was used to process the collected environment data. The average filtering method has the advantages of simple calculation, less time consuming and less storage, which was very suitable for embedded system.

Firstly, $\mathrm{n}$ data were continuously collected in the average filtering algorithm of anti-impulse interference. Secondly, the maximum and minimum values were found and deleted. The remaining N-2 data to do the average operation. Finally, the calculation results as the output data. $\mathrm{N}$ takes 4 in this paper in order to improve the response speed of the system.

The server software was developed based on SQL Server 2008, ASP. Net and visual studio 2010 web platform. It realizes realized the real-time storage of environmental parameters information. Meanwhile, the query web was developed in the server software, used to display environmental data. The Android terminal application software was developed on Android development platform with Eclipse configuration. And the Java programming language was used. Through it, the query web on the server for the henhouse environmental parameters can be viewed on the phone in real time [9-10].

\section{DESIGN OF THE MONITORING EXPERIMENTS}

The monitoring experiments were carried out in a laminated automatic control henhouse with six overlap tiers cages, which contains 4.5 million hens, of Hubei Shendan healthy food Co., Ltd, in Wuhan city from January 3 to February 2, 2016. The henhouse was $80.3 \mathrm{~m}$ long, $11.6 \mathrm{~m}$ wide and $6.0 \mathrm{~m}$ high. And it had four columns and five aisles. The cage in the henhouse used six layers of stacked cages (Guangzhou Huanan animal husbandry equipment Co., Ltd.), which were divided into upper and lower three floors with the middle of the steel management network. The longitudinal damp curtain ventilation system was installed in the henhouse.

According to the spatial structure of laminated henhouse and the distribution of the hens coop, a kind of monitoring 
distribution topology was designed. From the damp curtain to the fan port, The air temperature, relative humidity, light intensity, $\mathrm{CO}_{2}$, wind speed in four points are monitored which are $5.9 \mathrm{~m}, 20.9 \mathrm{~m}, 31.9 \mathrm{~m}, 53.5 \mathrm{~m}, 74.1 \mathrm{~m}\left(\mathrm{~L}_{5.9 \mathrm{~m}}, \mathrm{~L}_{20.9 \mathrm{~m}}\right.$, $\mathrm{L}_{31.9 \mathrm{~m}}, \mathrm{~L}_{53.5 \mathrm{~m}}, \mathrm{~L}_{74.1 \mathrm{~m}}$ ) of 5 aisles(Fig. 3a), respectively. Meanwhile, 6 points of $0.6 \mathrm{~m}, 1.3 \mathrm{~m}, 1.9 \mathrm{~m}, 3.1 \mathrm{~m}, 3.8 \mathrm{~m}$, $4.4 \mathrm{~m}\left(\mathrm{H}_{0.6 \mathrm{~m}}, \mathrm{H}_{1.3 \mathrm{~m}}, \mathrm{H}_{1.9 \mathrm{~m}}, \mathrm{H}_{3.1 \mathrm{~m}}, \mathrm{H}_{3.8 \mathrm{~m}}\right.$ and $\left.\mathrm{H}_{4.4 \mathrm{~m}}\right)$ (Fig. $3 \mathrm{~b}$ ) from the ground are monitored each aisle. The environmental parameters in each point were collected per one minute.

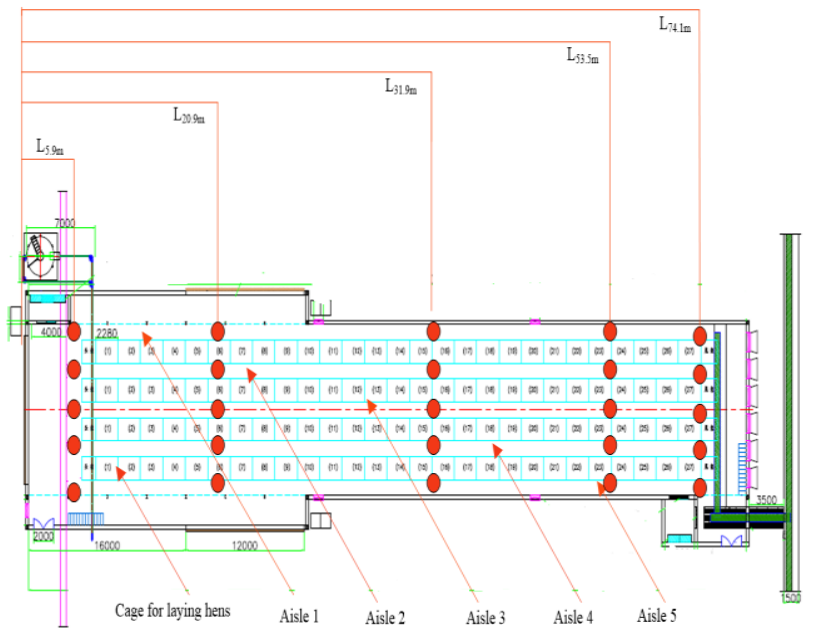

a. The topology of longitudinal henhouse aisles sampling points

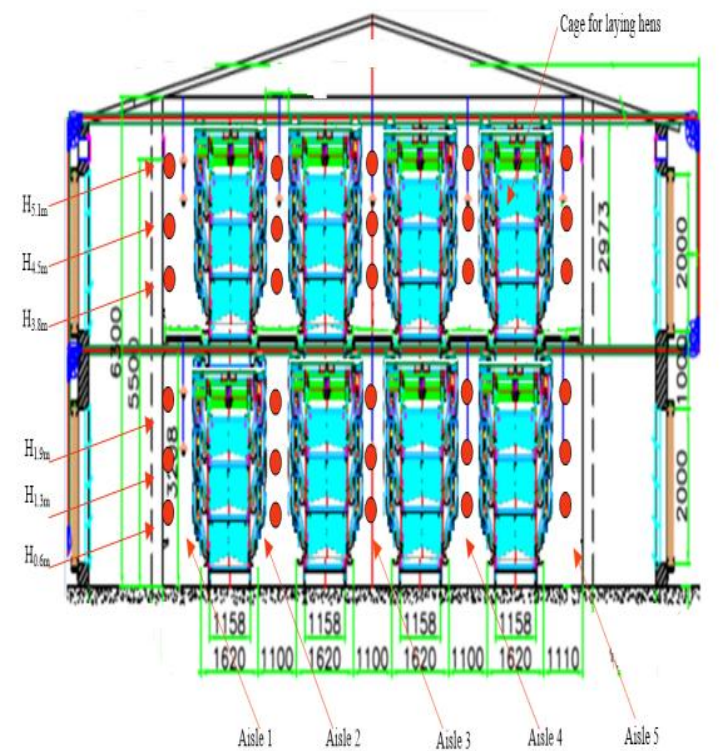

b. The topology of transverse henhouse aisle sampling points Note: The round in the fig a, b were the sampling points.

Figure. 3 Topology of henhouse aisle sampling points

\section{RESULTS AND DISCUSSION}

SPSS 18.0 was used for statistical analysis of the data and Duncan method was used to carry out significant test. $\mathrm{P}<0.05$ is the significant difference criterion. The results of henhouse environment parameters from the damp curtain to fan port were shown in TABLE I.
TABLE I. RESULTS OF TEMPERATURE, RELATIVE HUMIDITY, WIND SPEED, $\mathrm{CO}_{2}$

\begin{tabular}{|c|c|c|c|c|}
\hline \multirow{2}{*}{$\begin{array}{c}\text { Grou } \\
\text { p }\end{array}$} & \multicolumn{4}{|c|}{$\begin{array}{l}\text { Results of temperature, relative humidity, wind speed, } \\
\mathrm{CO}_{2}\end{array}$} \\
\hline & $\begin{array}{l}\text { Temperatur } \\
e\end{array}$ & $\begin{array}{c}\text { Relative } \\
\text { humidity } \\
\%\end{array}$ & $\begin{array}{c}\text { wind } \\
\text { speedm/s }\end{array}$ & $\underset{m g / m^{3}}{\mathrm{CO}_{2}}$ \\
\hline $\mathrm{L}_{5.9 \mathrm{~m}}$ & $16.694 .18^{\mathrm{a}}$ & $\begin{array}{l}68.7213 .1 \\
9^{\mathrm{a}}\end{array}$ & $0.090 .02^{\mathrm{a}}$ & $2423.72664 .91^{\mathrm{a}}$ \\
\hline $\mathrm{L}_{20.9 \mathrm{~m}}$ & $20.822 .27^{\mathrm{b}}$ & $\underset{\text { bd }}{56.277 .96}$ & $0.040 .01^{\mathrm{b}}$ & $2727.10389 .70^{b}$ \\
\hline $\mathrm{L}_{31.9 \mathrm{~m}}$ & $19.561 .54^{\mathrm{cd}}$ & $\underset{\mathrm{b}}{55.355 .81}$ & $0.130 .02^{\mathrm{a}}$ & $2420.61350 .64^{\mathrm{a}}$ \\
\hline $\mathrm{L}_{53.3 \mathrm{~m}}$ & $19.740 .97^{\mathrm{c}}$ & $\underset{\mathrm{b}}{55.643 .72}$ & $0.170 .02^{\mathrm{c}}$ & $2442.89305 .68^{a}$ \\
\hline $\mathrm{L}_{74.1 \mathrm{~m}}$ & $19.071 .33^{\mathrm{d}}$ & $\underset{\mathrm{de}}{57.774 .73}$ & $0.190 .02^{\mathrm{a}}$ & $2371.76274 .97^{a}$ \\
\hline
\end{tabular}

From TABLE I, the farther distance from the damp curtain, the bigger the value of temperature were. But relative humidity had a decrease trend. Wind speed at the point of $\mathrm{L}_{5.9 \mathrm{~m}}$ was significantly higher than that of $\mathrm{L}_{20.9}$, $\mathrm{L}_{31.9 \mathrm{~m}}, \mathrm{~L}_{53.5 \mathrm{~m}}$ and $\mathrm{L}_{74.1 \mathrm{~m}}(\mathrm{P}<0.05)$. The average concentration of $\mathrm{CO}_{2}$ is $2477.22 \mathrm{mg} / \mathrm{m}^{3}$, higher than $1500 \mathrm{mg} / \mathrm{m}^{3}$ of reasonable value, according to the livestock and poultry farm environmental quality standard (INY/T 388-1999), especially $\mathrm{L}_{20.9 \mathrm{~m}}$ at the highest concentration of carbon dioxide, significantly higher than other measurement points $(\mathrm{P}<0.05)$ [11].

The change of henhouse environment parameters at different height is shown in TABLE II.

TABLE II. RESULTS OF TEMPERATURE, RELATIVE HUMIDITY, WIND SPEED, LIGHT INTENSITY, $\mathrm{CO}_{2}$

\begin{tabular}{|c|c|c|c|c|c|}
\hline \multirow{2}{*}{$\begin{array}{c}\mathbf{G r} \\
\text { ou } \\
\mathbf{p}\end{array}$} & \multicolumn{5}{|c|}{$\begin{array}{l}\text { Results of temperature, relative humidity, wind speed, light } \\
\text { intensity, } \mathrm{CO}_{2}\end{array}$} \\
\hline & $\begin{array}{l}\text { Tempe } \\
\text { rature }\end{array}$ & $\begin{array}{c}\text { Relative } \\
\text { humidity\% }\end{array}$ & $\begin{array}{c}\text { wind } \\
\text { speedm/s }\end{array}$ & $\begin{array}{c}\text { Light } \\
\text { intensityLx }\end{array}$ & $\underset{m g / m^{3}}{\mathrm{CO}_{2}}$ \\
\hline $\begin{array}{l}\mathrm{H}_{0 .} \\
6 \mathrm{~m}\end{array}$ & $\begin{array}{c}18.193 \\
.08^{\mathrm{a}}\end{array}$ & $\underset{\mathrm{a}}{60.5410 .04}$ & $0.100 .01^{\mathrm{a}}$ & $54.699 .43^{\mathrm{a}}$ & $\begin{array}{c}2228.623 \\
53.81^{\mathrm{a}}\end{array}$ \\
\hline $\begin{array}{r}\mathrm{H}_{1} . \\
3 \mathrm{~m}\end{array}$ & $\begin{array}{c}18.272 \\
.27^{\mathrm{a}}\end{array}$ & $61.568 .13^{\mathrm{a}}$ & $0.110 .02^{\mathrm{a}}$ & $\underset{\mathrm{b}}{57.5412 .72}$ & $\begin{array}{c}2331.183 \\
20.48^{\mathrm{b}}\end{array}$ \\
\hline $\begin{array}{r}\mathrm{H}_{1} \\
9 \mathrm{~m}\end{array}$ & $\begin{array}{c}18.641 \\
.52^{\mathrm{a}}\end{array}$ & $61.307 .08^{\mathrm{a}}$ & $0.110 .02^{\mathrm{a}}$ & 58.9 & $\begin{array}{c}2487.652 \\
36.17^{\mathrm{c}}\end{array}$ \\
\hline $\begin{array}{r}\mathrm{H}_{3} \\
1 \mathrm{~m}\end{array}$ & $\begin{array}{c}21.912 \\
.62^{\mathrm{b}}\end{array}$ & $50.639 .14^{\mathrm{b}}$ & $0.090 .01^{\mathrm{a}}$ & 44.4511 .05 & $\begin{array}{c}2869.014 \\
80.85^{\mathrm{d}}\end{array}$ \\
\hline $\begin{array}{r}\mathrm{H}_{3} \\
8 \mathrm{~m}\end{array}$ & $\begin{array}{c}21.831 \\
.99^{\mathrm{b}}\end{array}$ & $51.177 .44^{\mathrm{b}}$ & $0.120 .02^{\mathrm{a}}$ & $41.079 .07 \mathrm{c}$ & $\begin{array}{c}2945.425 \\
35.97^{\mathrm{d}}\end{array}$ \\
\hline$\underset{4 \mathrm{~m}}{\mathrm{H}^{4}}$ & $\begin{array}{c}21.991 \\
.55^{\mathrm{b}}\end{array}$ & $50.566 .54^{\mathrm{b}}$ & $0.130 .03^{\mathrm{a}}$ & $39.166 .36^{d}$ & $\begin{array}{c}2956.715 \\
02.58^{\mathrm{d}}\end{array}$ \\
\hline
\end{tabular}

From TABLE II, the temperature and the concentration of $\mathrm{CO}_{2}$ of upper floors $\left(\mathrm{H}_{3.1 \mathrm{~m}}, \mathrm{H}_{3.8 \mathrm{~m}}\right.$ and $\left.\mathrm{H}_{4.4 \mathrm{~m}}\right)$ was significantly higher than that of and lower floors $\left(\mathrm{H}_{0.6 \mathrm{~m}}, \mathrm{H}_{1.3 \mathrm{~m}}\right.$ and $\left.\mathrm{H}_{1.9 \mathrm{~m}}\right)(\mathrm{P}<0.05)$. With the increase of cage layers height, the concentration of $\mathrm{CO}_{2}$ and the wind speed were increasing. But relative humidity and light intensity had a decrease trend.

Related research showed the environmental quality were different among different measuring points. The temperature 
in the henhouse met the requirement of national environmental quality standard of livestock and poultry farm, but the concentration of $\mathrm{CO}_{2}$ was too higher. It was recommended that strengthening the ventilation management on the basis of keeping suitable temperature, to improve the environmental quality for better production performance of layers [12-13].

\section{CONCLUSIONS}

An intelligent monitoring system for the laminated henhouse with six overlap tiers cages and a kind of monitoring topology were designed in the paper. It can realize the real-time online monitoring of environmental parameters of the henhouse. Through intelligent mobile APP, the users can make query to the henhouse environment realtime data. The monitoring experiment was carried out in a henhouse in Hubei province. And the evaluation of the henhouse environment was scientifically analyzed. In fact, we find that his system runs stably, accurately and effectively, and has important practical significance and good application prospect in large-scale livestock precision farming. More precise measurements and reasonable monitoring topology for laminated henhouse should be researched in further work. And the monitoring solution for different types of poultry should be considered.

\section{ACKNOWLEDGMENT}

The authors thank the financial support by National Key Research and Development Program (2016YFD0800901-03); National Key Technology Research and Development Program of the Ministry of Science and Technology of China (2014BAD08B11); National Natural Science Foundation of China (61273329, 31601268); Program 863 (SS2013AA102302). And thank Hubei Shendan healthy food Co., Ltd for providing experimental conditions.

\section{REFERENCES}

[1] LEINONEN I, WILLIAMS A G, WISEMAN J, et al. Predicting the environmental impacts of chicken systems in the United Kingdom through a life cycle assessment: Egg production systems[J]. Poultry Science, 2012, 91(1): 26-40.

[2] HOLT P S, DAVIES R H, DEWULF J, et al. The impact of different housing systems on egg safety and quality[J]. Poultry Science, 2011, 90(1): 251-262

[3] ZHAO Y, SHEPHERD T A, LI H, et al. Environmental assessment of three egg production systemsPart I: Monitoring system and indoor air quality[J]. Poultry Science, 2015, 94(3): 518-533.

[4] Bekmezci I, Sahingoz O K, Temel S. Flying Ad-Hoc networks (FANETs): A survey[J]. Ad Hoc Networks, 2013, 11(3): 12541270.

[5] Leea W S, Alchanatis V, Yang C, et al. Sensing technologies for precision specialty crop production[J]. Computers and Electronics in Agriculture, 2010, 74(1): 233.

[6] W.S. Lee, V. Alchanatis, et al. Sensing technologies for precision specialty crop production[J]. Computers and Electronics in Agriculture, 2010, 74 (1) : 2 33.

[7] Gao T. Methodological Research on Environmental Control of Ultralarge Scale Automated Laying Hen Houses[D]. Masters Dissertation. Yangling: Northwest Agriculture and Forestry University, 2013, 6.

[8] WANG M, HAN T L. Effects of Heating Stress on Layers and Protective Practices[J]. Chinese Animal Husbandry and Veterinary Medicine.2011, 38(2): 209-211.

[9] XIN H, GATES R S, GREEN A R, et al. Environmental impacts and sustainability of egg production systems[J]. Poultry Science, 2011, 90(2): 263-277.

[10] Evy Troubleyn, Ingrid Moerman, Piet Demeester. QoS challenges in wireless sensor networked robotics $[\mathrm{J}]$. Wireless Personal Communications, 2013, 70(3): 10591075.

[11] NY/T388-1999. National environmental quality standard of livestock and poultry farm[S]. Beijing: Ministry of Agriculture of the Peoples Republic of China. 1999.

[12] Mianxiong Dong, Kaoru Ota, Man Lin, et al. UAV-assisted data gathering in wireless sensor networks [J]. The Journal of Supercomputing, 2014, 70 (3): 11421155.

[13] Sharma V, Kumar R. A cooperative network framework for multiUAV guided ground Ad Hoc networks[J]. J Intell Robot Syst, 2015, 77(3/4): 629652 . 